\title{
SCIENTIFIC REP RTS \\ OPEN Author Correction: The global view of mRNA-related ceRNA cross-talks across cardiovascular diseases
}

Chao Song ${ }^{1}$, Jian Zhang ${ }^{2}$, Hanping $\mathrm{Oi}^{1}$, Chenchen Feng

Correction to: Scientific Reports https://doi.org/10.1038/s41598-017-10547-z, published online 31 August 2017

The original version of this Article contained an error in the order of corresponding authors. This error has now been corrected in the PDF and HTML versions of the Article.

(i) Open Access This article is licensed under a Creative Commons Attribution 4.0 International License, which permits use, sharing, adaptation, distribution and reproduction in any medium or format, as long as you give appropriate credit to the original author(s) and the source, provide a link to the Creative Commons license, and indicate if changes were made. The images or other third party material in this article are included in the article's Creative Commons license, unless indicated otherwise in a credit line to the material. If material is not included in the article's Creative Commons license and your intended use is not permitted by statutory regulation or exceeds the permitted use, you will need to obtain permission directly from the copyright holder. To view a copy of this license, visit http://creativecommons.org/licenses/by/4.0/.

(c) The Author(s) 2018
${ }^{1}$ Department of Pharmacology, Harbin Medical University-Daqing, Daqing, 163319, China. ${ }^{2}$ Department of Medical Informatics, Harbin Medical University-Daqing, Daqing, 163319, China. Chao Song, Jian Zhang and Hanping Qi contributed equally to this work. Correspondence and requests for materials should be addressed to H.S. (email: shlhmu@163.com) or C.L. (email: Icqbio@163.com) 